\title{
The Arctic Exploits of Dr. Octave Pavy
}

\author{
Douglas W. Wamsley ${ }^{1}$
}

(Received 2 January 2014; accepted in revised form 26 May 2014)

\begin{abstract}
Dr. Octave Pierre Pavy served as the physician for the ill-fated Lady Franklin Bay Expedition of $1881-84$, one of two expeditions supported by the United States during the First International Polar Year. He was one of 18 members of the expedition who died at the tragic camp at Cape Sabine while awaiting a relief party. Unlike the other members of the expedition, who volunteered from frontier outposts in the American West with no Arctic experience, Pavy joined the expedition with considerable knowledge and first-hand experience in living and traveling the Arctic regions. For him, the Lady Franklin Bay Expedition was the culmination of a two-decade obsession with polar exploration and a fervent desire to make a name for himself in the far North. However, Pavy's personality shortcomings and his long-running feud with his commander, Lieutenant Adolphus W. Greely, which featured prominently in Greely's narrative and official reports and in subsequent published accounts, have overshadowed nearly all other aspects of Pavy's character, as well as his accomplishments. Although those negative aspects cannot be overlooked in any assessment, a more thorough examination of Pavy's Arctic endeavors reveals a mixed record of performance that included laudable service in his primary role as physician and also in varied tasks in support of the expeditions with which he was involved.
\end{abstract}

Key words: Pavy; Greely; Howgate; Gulnare; Lambert; Doane; Silas Bent; Lady Franklin Bay; Cape Sabine; open polar sea

RÉSUMÉ. Le D ${ }^{\mathrm{r}}$ Octave Pierre Pavy était le médecin de l'infortunée expédition de la baie Lady Franklin entre 1881 et 1884 , soit l'une des deux expéditions appuyées par les États-Unis pendant la première année polaire internationale. Il faisait partie des 18 membres d'expédition qui ont trouvé la mort au tragique campement de cap Sabine en attendant la relève. Contrairement aux autres membres de l'expédition, des volontaires des fronts pionniers de l'Ouest américain sans expérience de l'Arctique, le $\mathrm{D}^{\mathrm{r}}$ Pavy possédait beaucoup de connaissances et d'expérience pratique en matière de vie et de déplacements dans les régions arctiques. Pour lui, l'expédition de la baie Lady Franklin constituait le point culminant d'une obsession d'une vingtaine d'années avec l'exploration polaire et un ardent désir de se faire un nom dans le Grand Nord. Toutefois, les lacunes inhérentes à sa personnalité et sa querelle de longue date avec son capitaine, le lieutenant Adolphus W. Greely - querelle dont il est souvent question dans les textes et les rapports officiels d'Adolphus Greely et dans des récits publiés ultérieurement - ont éclipsé presque tous les autres aspects du personnage de Pavy et de ses réalisations. Bien que ces aspects négatifs ne puissent être négligés, l'examen plus poussé des entreprises du $\mathrm{D}^{\mathrm{r}}$ Pavy dans l'Arctique laisse entrevoir un rendement contrasté, assorti d'un service louable en tant que médecin, son rôle principal, ainsi que dans le cadre des diverses tâches où il a prêté main-forte pendant les expéditions dont il a fait partie.

Mots clés : Pavy; Greely; Howgate; Gulnare; Lambert; Doane; Silas Bent; baie Lady Franklin; cap Sabine; mer polaire ouverte

Traduit pour la revue Arctic par Nicole Giguère.

\section{EARLY YEARS}

Octave Pierre Pavy was born in the city of New Orleans, Louisiana, on 22 June 1844, the younger of two sons of Pierre Joseph and Caroline Pavy (Pavy, 1884:115). Pierre Joseph Pavy had emigrated from France to New Orleans at an early age and established himself as a successful businessman. His wife, Caroline Pavy, nee Rentrop, was the daughter of a prominent plantation family in St. Mary Parish, Louisiana. In the Antebellum South of the United States, New Orleans was the world's largest exporter of cotton, and Pierre Joseph Pavy made his fortune as a successful cotton commission merchant, acting as an agent for the rural plantation owners in bringing their cotton crop to market. The prosperous Pavy family could afford to send their son Octave to France for a formal European education.

While abroad for several years, Octave Pavy enjoyed a privileged lifestyle, spending considerable leisure time touring the major cities and resorts of Europe. At ease among the cultured class, he made the acquaintance of the European master artists and acquired a discerning eye in the art world. According to Lilla May Pavy, Octave's future wife, Octave became "a connoisseur on questions of artistic merit," which led to his honorary membership in several art societies (Pavy, 1884:116). In 1864, Octave graduated from the highly regarded and competitive Lycée Napoléon

\footnotetext{
${ }^{1}$ Ridgewood, New Jersey, USA; wamsleyd@msn.com

(C) The Arctic Institute of North America
} 
(now the Lycée Henri-IV) and enrolled in medical school at the University of Paris. Through Pierre Pavy's influence, Octave had the benefit of working alongside Alfred Armand Velpeau, clinical chair at the University of Paris, who was considered the leading surgeon in 19th-century France. Although Octave had significant clinical experience and passed the first of his medical examinations in November 1866, he did not complete all the formal requirements for his medical degree (Pavy, 1866). Nevertheless, he left the University of Paris with the basic skills necessary to practice medicine, a profession that would provide him with opportunities in the far North throughout his life. However, Pavy's upscale background and his acceptance among Europe's elite at an impressionable young age may have also contributed to a sense of self-importance and superiority that would affect his subsequent personal dealings.

\section{FRENCH NORTH POLE EXPEDITION 1867-70}

While still in France, Pavy's interest turned almost exclusively to one subject, the exploration of the North Polar regions. He would rarely be distracted from this passion for the rest of his life. Pavy's Arctic interest was sparked by a lecture on the subject of the exploration of the North Pole by Gustave Lambert, a hydrographer with the French government. Lambert spoke from firsthand experience, having served on a whaling voyage to the Bering Strait region in June 1865. That cruise plied the broken ice of the North Pacific Ocean for three months, reaching as far as $72^{\circ} \mathrm{N}$ latitude (Pavy, 1868:306). At the time he met Pavy, Lambert had begun to formulate his own plan, based on his western Arctic experience, for a voyage to the North Pole.

Following their initial acquaintance, Lambert and Pavy became close friends. Lambert shared his polar idea with his awestruck acquaintance, and both became captivated with the subject of a North Polar expedition, so much so that "there was not a day or night in which M. Pavy and M. Lambert were not mutually interested and similarly engaged" (Pavy, 1884:116). According to family lore, Octave Pavy became so obsessed with an Arctic voyageand his father so opposed it - that he promised his son an independent fortune if he would drop his polar pursuit for a career in medicine. But the headstrong Octave did not change his mind.

A surviving early photographic image of Octave Pavy portrays a well-dressed young man, refined and superbly confident, as consistent with his privileged upbringing (Fig. 1). Although it is not apparent from the photo, Pavy's commanding physical presence added an air of authority. He was most authoritative on Arctic science and exploration; profoundly well read, he considered himself an expert on every aspect of the subject. But Pavy carried his obsession to an extreme: those familiar with him frequently used the term "monomaniac" to define his personality (Weber, 1883; Anon., 1884a).

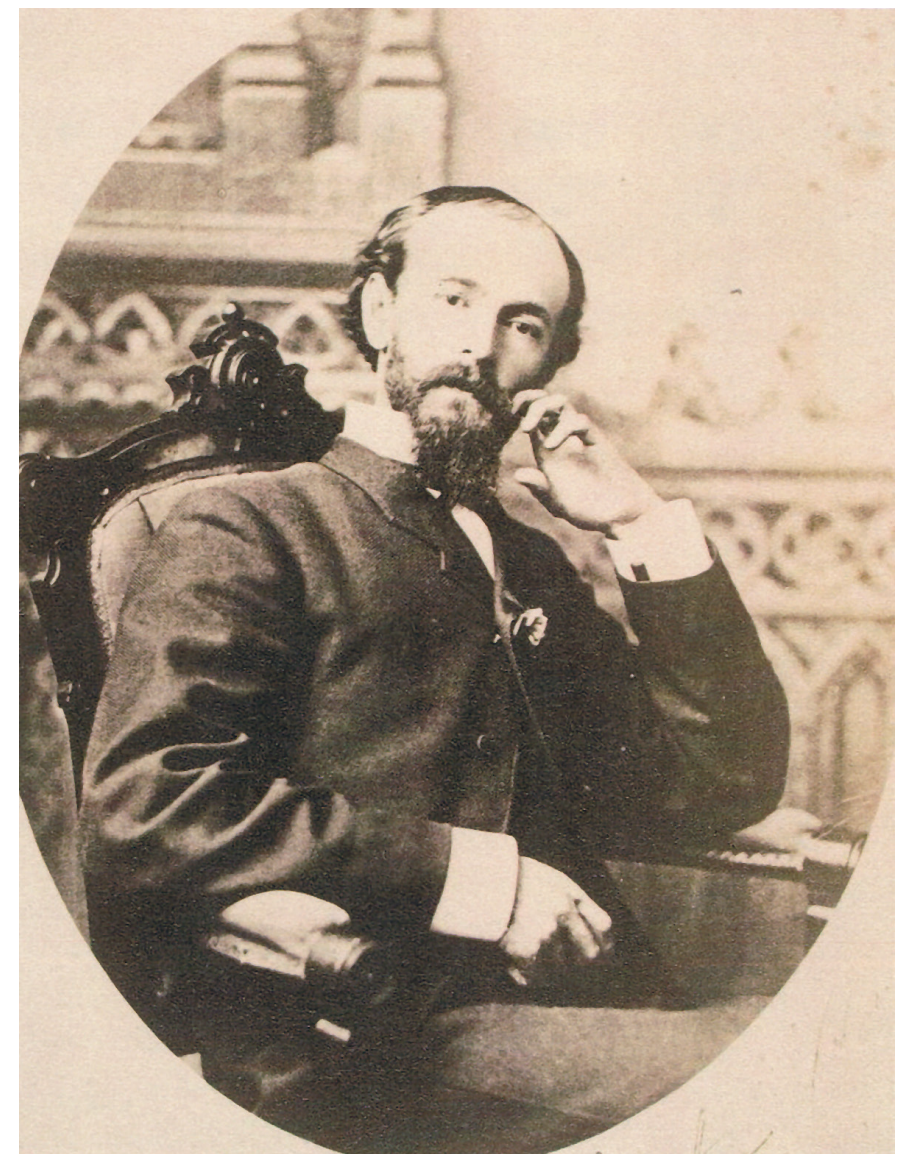

FIG. 1. Octave Pierre Pavy (1844-1884) (courtesy of the Bibliothèque nationale de France).

Pavy's newfound interest in the North Pole developed during the $1860 \mathrm{~s}$, at a time of increased European interest in the Arctic. After the search for explorer Sir John Franklin ended with the return of Sir Leopold McClintock's Fox expedition in 1859 , further northern exploration could be justified only for purely geographical or scientific purposes. In 1860-61, an American, Dr. Isaac Israel Hayes, organized and led the first modern expedition with the stated objective of reaching the North Pole (that is, the geographic pole). The expedition failed to reach the pole, and even Hayes's claim to have attained a record high northern latitude by land along the Ellesmere Island coast of Smith Sound has been largely rejected (Holland, 1994:257). However, from that disputed record high location, Hayes (1867) claimed that he had spied the legendary "Open Polar Sea," a vast region of open water in the High Arctic, largely free of ice, that stretched northward towards the Pole. Earlier explorers had also argued for an "Open Polar Sea" within Smith Sound. British seaman Commander Edward Inglefield had made a brief excursion into the sound during the search for Sir John Franklin in August 1852. Passing its entrance at Cape Alexander, he noted that it "must lead to the great Polynia of the Russians" (Inglefield, 1853:220). The expedition of American explorer Dr. Elisha Kent Kane, while also searching for Franklin, extended Inglefield's discoveries in 
Smith Sound, and Kane claimed to have observed a large area of open water in June 1854 (Kane, 1856, Vol. 1:302).

The open polar sea would prove elusive to later explorers, but Hayes's polar attempt sparked further efforts to discover the North Pole as a prize in its own right. On 23 January 1865, the British navigator Sherard Osborn delivered a paper to the Royal Geographical Society entitled "On the Exploration of the North Polar Region" (Osborn, 1864-65). Osborn's plan called for another attempt on the North Pole from the direction of Smith Sound, using two steamships. He believed that this route offered the least risk and greatest probability of success, given the availability of a starting point on land nearer to the Pole than Spitsbergen.

German geographer Augustus Petermann, however, had his own views on how to reach the Pole, which contrasted markedly with Osborn's plan. Capitalizing on the spirit of nationalism sparked by the success of Otto von Bismarck in uniting the German states, Petermann advocated a German national expedition. However, his idea was to achieve the North Pole through an open polar sea, which could be reached by penetrating the pack ice to the east of Greenland and west of Svalbard (Petermann, 1864-65). Petermann's advocacy led to the first German exploring expedition, that of the Germania under the command of Captain Karl Koldewey. Between May and September 1868, Germania skirted the East Greenland and Svalbard coasts, but ice and a lack of steam power prevented the achievement of any significant results (Holland, 1994:274).

Against this backdrop, Lambert had sought to capitalize on the continental spirit of nationalism by appealing to the French government. He had proposed yet a third route to reach the Pole, through the Bering Strait. Lambert's plan was bolstered by the theories of Captain Silas Bent, an officer with Commodore Matthew Perry's expedition to Japan in 1853 , who had compiled hydrographic observations to reach his own conclusions on the currents of the North Pacific Ocean. Bent claimed that just as there existed a Gulf Stream in the Atlantic, a similar warm-water "riverocean" existed in the Pacific, called the Kuro-Siwo or Japan Stream, a branch of which flowed northward through the Bering Strait. It seemed reasonable to Bent that the great warm currents of the Kuro-Siwo penetrated the Arctic Ocean until they met in an open polar sea. The best way to reach the Pole, according to Bent, was to follow the KuroSiwo through the Bering Strait and northward to the Pole (Bent, 1857).

The Emperor Napoleon III, aroused by European activity in the North, lent his endorsement to Lambert's plan and contributed 50000 francs toward the project. In the meantime, Lambert (dubbed "Peter the Hermit" for his Arctic zeal) carried on a heavy lecture tour throughout France to solicit further support (Anon., 1868). On 20 December 1867, Lambert formally presented the full details of his plans to the Société de Géographie in Paris (Lambert, 1867) (Fig. 2). Pavy was named assistant chairman of the society's expedition committee, and he threw his support behind the project.

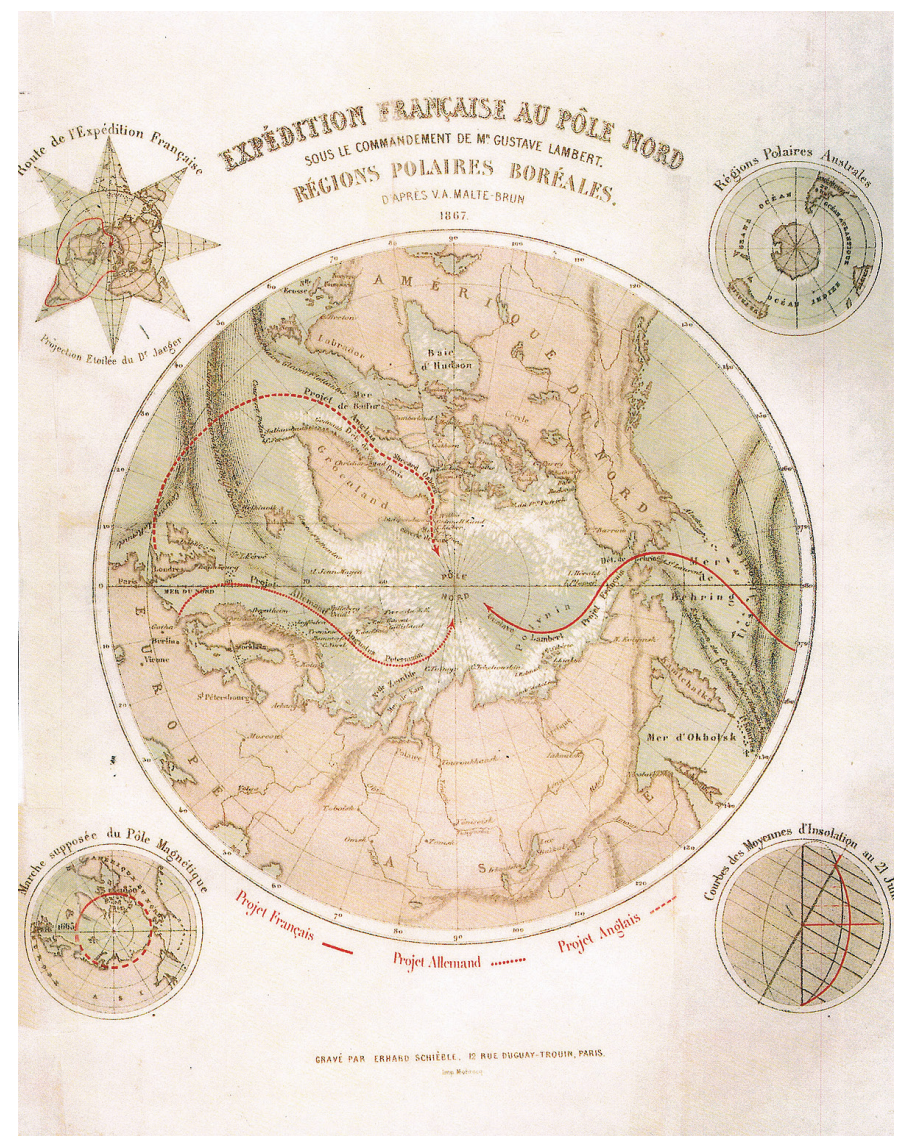

FIG. 2. Map of projected French expedition to the North Pole through the Bering Strait under the command of Gustave Lambert (solid line, at right). Also shown are the routes of planned English (dashed line, left) and German (dotted line, center) polar expeditions (Lambert, 1867).

Octave Pavy was a dreamer on a quixotic pursuit. The tantalizing glimpse of the fabled open polar sea, thought to have been observed by the physician-explorers Elisha Kent Kane and Isaac Israel Hayes and so eloquently portrayed in their writings, left a marked impression on the young Pavy, and in his own words, "profoundly moved my imagination" (Pavy, 1888:169). That these Arctic pioneers were also physicians who had relinquished the comfort of a customary medical practice to pursue their own destiny in the far North would have further inspired Pavy, a well-educated man of science with a background in the same field.

A lengthy and well-researched article written by Pavy and published in the popular and widely read Revue des Deux Mondes in September 1868 presented Lambert's plan to the public. Besides providing a comprehensive history of North Pole attempts, Pavy's article also cited firsthand support for the viability of the Bering Strait route from a recently returned whaler, Captain Thomas Long of the Nile (Pavy, 1868). Captain Long claimed to have observed open water in March 1867 from a point north of Siberia near where Baron von Wrangel had claimed to have seen open water in 1823. Although ice conditions may have been favorable, preparations for taking advantage of those conditions progressed frustratingly slowly. It was only by late 1868 that Lambert had managed to collect the minimum 


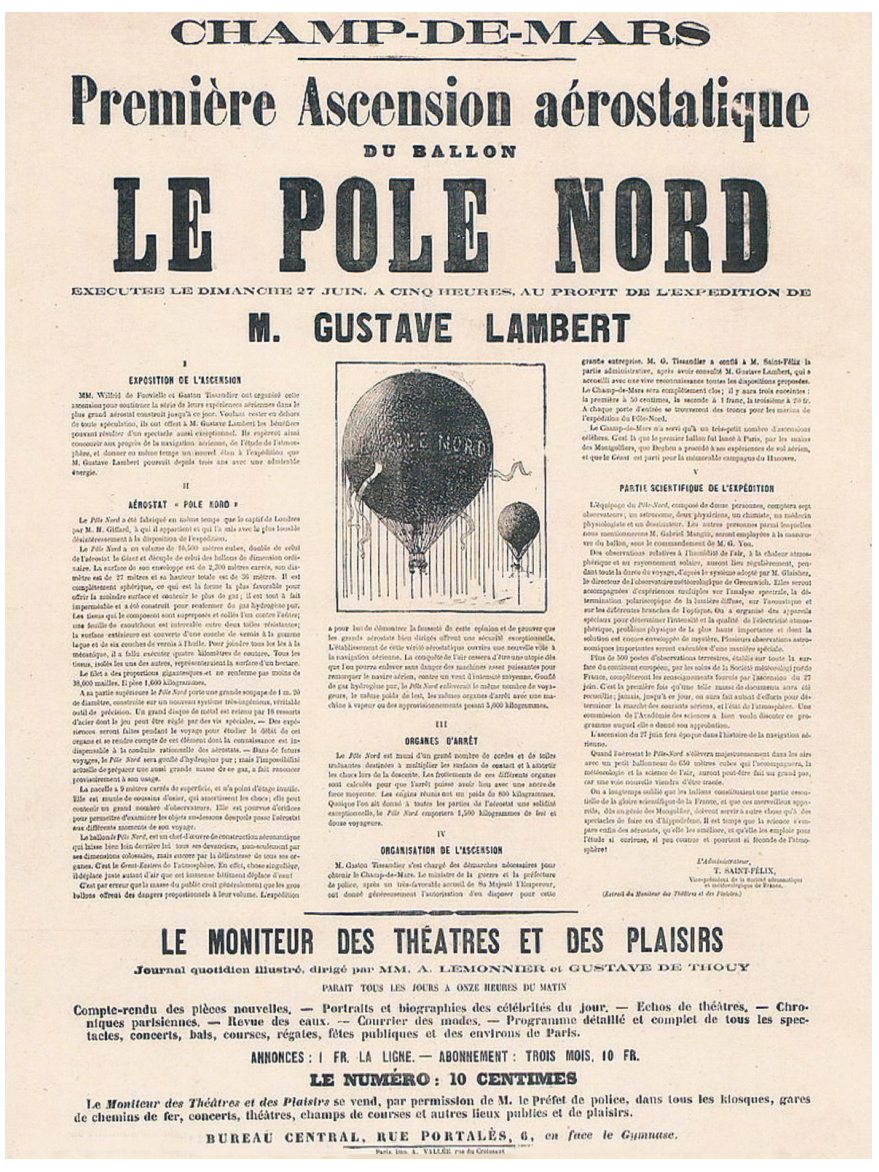

FIG. 3. Advertisement for the ascent of Wilfrid de Fonvielle's balloon Le Pole Nord in support of Gustave Lambert's Polar Expedition.

funds necessary to pay for the expedition. By February 1869, a 1000-ton, three-masted vessel, named the Boreal, had been purchased and outfitted in Le Havre as the expedition inched towards a possible departure.

A novel fundraising effort for the expedition was offered by the noted balloonist Wilfrid de Fonvielle, who had constructed the world's largest hydrogen balloon, aptly named "Le Pole Nord," which towered a full five stories high (Fig. 3). The modest proceeds from a trial launch of the balloon from the Champ de Mars (the open field adjacent to the Eiffel Tower) on 27 June 1869 were contributed to the expedition (Anon., 1869). By May 1870, however, matters finally looked encouraging: it was reported that the final funds had been obtained and a February 1871 departure date arranged. Optimistic editorial writers had hoped that by August $1871 \mathrm{Mr}$. Lambert would "plant the French flag on the prolongation of the terrestrial axis" (Liégard, 1870).

However, more significant international events transpired to sound the death knell to the venture after more than three years of effort on the part of Lambert and Pavy. On 19 July 1870, France had declared war on Prussia, commencing the devastating 10-month Franco-Prussian War. Despondent over the collapse of the Arctic venture, but nevertheless faithful to his homeland, Lambert took up the call to arms on behalf of his country. Tragically, Lambert was killed by Prussian artillery at the Battle of Buzenval during the siege of Paris on 21 January 1871, effectively ending any remaining hope for the expedition.

Pavy's close personal relationship with the nationalistic Lambert may have also had the effect of stimulating his own spirit of French patriotism. Confidence in his own abilities led the young Pavy to assume a position of leadership. Among the volunteer corps mustered on behalf of the French flag was a group of French loyalists, termed "La Guérille Noire," organized and commanded by Octave Pavy, who adopted the title of Captain. Their mission was to act independently of the regular French forces and conduct a system of guerilla warfare (Anon., 1871). Little is known of Pavy's service for the La Guérille Noire from its organization through the end of the war in May 1871. One somewhat improbable story claimed that the celebrated artist Henri Regnault died at Pavy's side during the siege of Paris (Pavy, 1886a:259-260). Another story claimed that Pavy was captured by the Germans near Gravelotte and condemned to execution; however, while he was being escorted to the place of the execution, a French detachment liberated Pavy, carrying him away on horseback (Anon., 1886a). Lilla May Pavy's connection with the publication of both these stories suggests that she was the source, perhaps in an overzealous effort to fashion a more heroic image of her husband. More importantly, however, for the independent-minded Pavy, participation in La Guérille Noire had offered the optimal means of military service, one in which Pavy held the leadership position, but was unburdened by the formal military discipline to which the regular French corps was subject.

\section{PAVY'S PROPOSED PRIVATE EXPEDITION TO THE NORTH POLE 1871-73}

With his unfulfilled French Arctic endeavor behind him, in May 1871 Pavy returned to the United States, arriving with letters of introduction to various geographical and scientific societies provided by the Société de Géographie. $\mathrm{He}$ at once set about to seek funds from the U.S. government for a plan along the lines of Lambert's original but forestalled proposal. At the rooms of the American Geographical Society in New York City, he met the remarkable explorer Charles Francis Hall, then preparing to depart for his own expedition to the North Pole through Smith Sound in the steamship Polaris (Pavy, 1884:117). Since Hall's newly proposed North Pole expedition had been backed by the U.S. government only after a prolonged and hardfought campaign by Hall and his supporters, it was obvious to Pavy that it would be impossible to gain further U.S. government support for his own expedition. Therefore, the persistent Pavy set about organizing a private expedition funded by wealthy financial backers.

On the stiflingly hot summer evening of 26 June 1871, Pavy was present at the exquisite Great Hall of Cooper Union in New York City for the send-off meeting for the Polaris expedition arranged by the geographical society. 
Pavy looked on longingly as the unrefined but experienced Hall told his audience with great enthusiasm his plan to cross the open polar sea and reach the North Pole. Although Hall and his expedition took center stage that night, Colonel T.B. Myers, one of the society's councilors, took a few moments to introduce Pavy and offer a few words of support for his expedition (Daly, 1873:411-412). The support from the American Geographical Society was somewhat surprising given Pavy's improbable plan, his lack of Arctic experience, and perhaps most importantly, the position of its president, Charles P. Daly, a prominent New York State judge. Speaking at his annual address to the society in 1870, Daly had remarked bluntly that the question of the open polar sea was "too unsettled and uncertain to be accepted as fact" (Daly, 1870:cxxv). As for Bent's theory that a warm water current penetrated the Bering Strait, which provided the basis of Pavy's North Pole attempt, Daly (1870:cxxv) had similarly opined that "not a single fact that I have been able to discover supports it." Nonetheless, Daly was an active supporter of exploration in general, and by means of a personal request to Baron von Lutke, vice-president of the Imperial Russian Geographic Society of St. Petersburg, he obtained the pledge of the Russian organization to provide Pavy with all the assistance it could muster in eastern Siberia.

Although Daly rejected Bent's theory, Pavy still fully embraced it. In early 1872, Pavy made a pilgrimage to visit Bent, then a retired naval surveyor living in St. Louis, and the two shared their ideas regarding the practicability of the Bering Strait route. Setting his sights on San Francisco as the starting point for his venture, Pavy set about looking for some deep-pocketed supporters who could make it a reality. The gold rush of the $1840 \mathrm{~s}-50 \mathrm{~s}$ had attracted thousands of fortune seekers, and by 1872 the city boasted a number of wealthy entrepreneurs, some of whom had made millions in speculative mining claims. Pavy's far-fetched polar scheme sought to appeal to the speculative side of the city's more well-to-do citizens.

Pavy's announced plan was to travel to the city of Petropavlovsk on the Kamchatka peninsula, starting in mid-summer, and there obtain furs, the remaining stores needed, and additional native support members. From Petropavlovsk, the party would sail to the Gulf of Anadyr on the far northeastern Siberian coast, a region blocked by ice a full 10 months of the year. From there, Pavy planned to travel overland a distance of 300 miles westward to Mys Yakan on the northern Siberian coast. To reach Mys Yakan would have been a monumental task by itself, but from there Pavy envisioned the start of a several hundred mile sledge journey with $40-50$ dogs as far north as Wrangel Land, where he expected to reach the open polar sea. (Whether "Wrangel Land" was an island or a land mass that extended to the North Pole, as some had suggested, was unclear at the time.) Then, launching a custom built "raft" of sorts, Pavy intended to cross the North Pole and return via the currents to Smith Sound, Baffin Bay and the Atlantic Ocean. The all-important "raft" upon which he planned

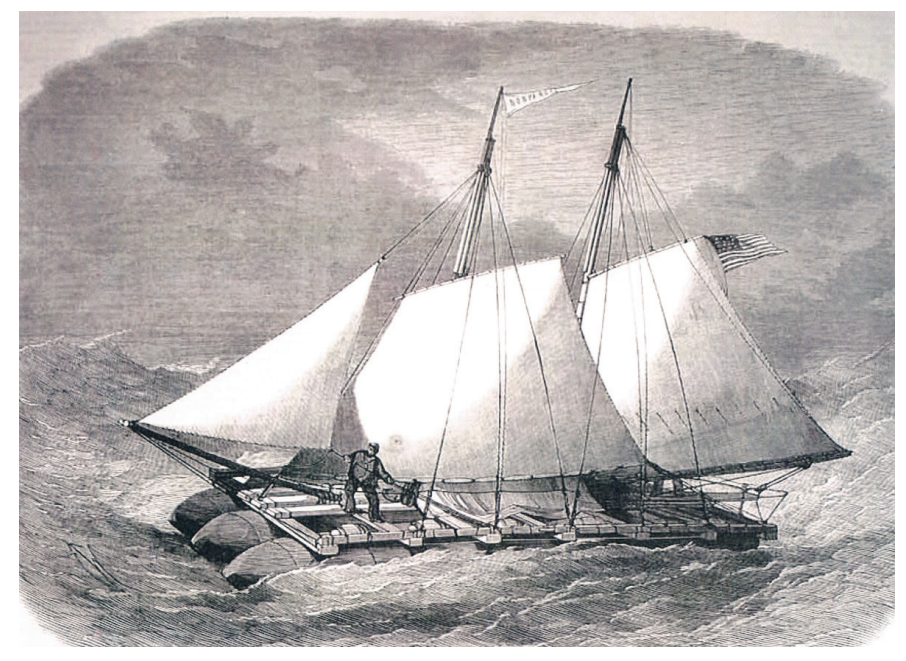

FIG. 4. The Nonpareil at Sea (Illustrated London News, 16 August 1867).

to traverse 1000 miles of open water across the Pole was to be made from gutta percha, a form of latex derived from certain tropical trees (Walker, 1872:550-551).

The novel use of a rubber raft to navigate among the most hazardous seas in the world was advocated by Captain John Mikes, who in 1867 had used a similar vessel (named the Nonpareil) to cross the Atlantic Ocean in 43 days (Fig. 4). The Pavy raft would consist of four hollow, cigarshaped cylinders of gutta percha fabric, lashed together and attached to a deck of wooden slats, upon which a mast and a canvas tent for shelter were erected. Captain Mikes was so confident in its navigation on the icy seas that he offered to join the expedition. Also volunteering for the expedition was Dr. George Chismore, a former U.S. Army officer and a participant in the Western Union Telegraph expedition to Alaska in 1865-66. In San Francisco on 5 June 1872, Pavy addressed the California Academy of Sciences with the full details of his plan. To Pavy's surprise, his proposal was met with outright hostility by Academy president George Davidson. An eminently practical man, with many years of experience surveying the Pacific Coast for the U.S. Coast and Geodetic Survey, Davidson bluntly advised Pavy that he "would as soon expect to find an ice-cream mountain in Africa as a warm Polar basin" (Davidson, 1872:572). To Davidson, the narrow Bering Strait could not possibly support a vast open polar sea on the scale envisioned by Pavy and Bent (Davidson, 1872:572-573). Nonetheless, the scientific society wished Pavy well in his endeavor.

Despite all his detailed planning and support, the Pavy North Pole expedition ended with little fanfare and publicity, under somewhat mysterious circumstances, never having departed San Francisco. Supporters were left with conflicting information about its status. Dr. David Walker, surgeon on board the Fox expedition and an acquaintance of Pavy, believed that the expedition had left San Francisco in May 1872 (Walker, 1872:550), and the New York Times reported on 23 June that Mr. Pavy "either started or is just about to start" from San Francisco (Anon., 1872a). In fact, the expedition never left San Francisco. The publicly 
declared reason for its cancellation was the alleged death of its unidentified principal financial backer, either by suicide or by his valet. Adding to the drama was the circumstance that the deed was reported to have occurred while Pavy was being feted by the California Academy of Sciences on the eve of his departure (Pavy, 1884:118). However, a slightly more inquisitive San Francisco reporter had done some detective work and concluded that all was not well with the financial affairs of the expedition and that Pavy may have secretly left San Francisco to dodge creditors and substantial bills (Anon., 1872b).

\section{MIDDLE YEARS OF OBSCURITY}

Many a planned polar expedition has failed, but few, if any, explorers took the failure as hard as Octave Pavy. The disappointing collapse of Pavy's North Pole expedition, his second failed polar attempt after another single-minded, energetic pursuit, hit Pavy particularly hard, leaving him in a prolonged state of depression and despair. Pavy was so dismayed by these events that he rejected a generous employment offer from William Chapman Ralston, a wealthy financier and founder of the Bank of San Francisco (Pavy, 1884:118-119). Instead, an embittered Pavy drifted aimlessly eastward from San Francisco, ultimately taking rooms in a $\log$ cabin outside the city of Liberty, Missouri.

Repudiating his privileged status and lifestyle, Pavy accepted odd jobs to make ends meet, at times reduced to depending on his own efforts as a fisherman for his next meal. Perhaps exaggerating slightly, Lilla May Pavy remarked that "with thread-bare, and more often ragged apparel, with broken health, and a grandly lofty spirit, this victim [Octave Pavy] of the "stings and arrows of outrageous fortune' passed four dark and melancholy years" (Pavy, 1884:119). However, even during his darkest hours, Pavy never abandoned his Arctic interest or his desire to explore the Arctic regions. Finally, his fortune took a decided turn for the better through his friendship with a prominent physician in Liberty, who opened his office and his library to Pavy and rekindled his interest in the practice of medicine.

The town of Liberty held more good fortune for Pavy. In September 1877, he met Lilla May Stone, then a teacher of private literary and music classes (Fig. 5). Their fondness for each other quickly grew, and they were married on 28 February 1878. Although deeply in love with Lilla May from the time of their first acquaintance, Octave made no secret of an overwhelming desire to make a name for himself as an Arctic explorer, a condition that Lilla May not only willingly accepted but actively supported.

The Arctic opportunity soon presented itself in the summer of 1878, when the flamboyant publisher of the New York Herald, James Gordon Bennett, solicited Octave as naturalist for his Jeannette expedition then being organized (Pavy, 1886a:260). Bennett proposed that the Jeannette, under the command of George Washington De Long, would

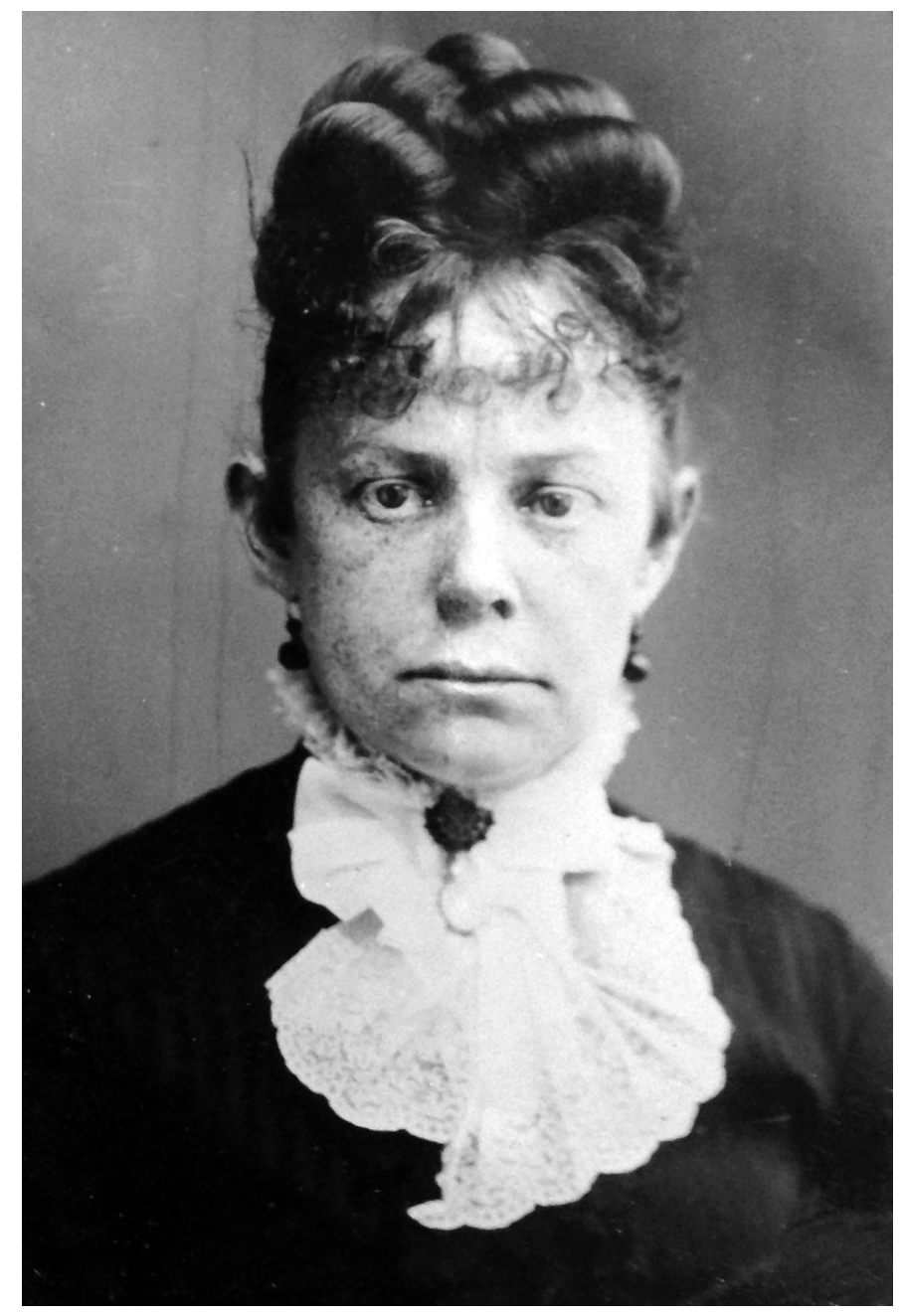

FIG. 5. Lilla May Pavy (courtesy of the Explorers Club).

sail through the Bering Strait and follow the coast of Wrangel Land northward, along the same track that Pavy had advocated for his own North Pole endeavor. However, the coveted position as naturalist was ultimately offered to Raymond Lee Newcomb of Salem, Massachusetts, a favorite of Professor Spencer Fullerton Baird at the Smithsonian Institution, who held the final say in the matter (Guttridge, 1987:81). Settling in St. Louis, Pavy enrolled at the Missouri Medical College (now Washington University School of Medicine), and with his previous medical education at the University of Paris, completed sufficient course work to satisfy the requirements for a medical degree within one year, graduating in March 1879 (Pavy, 1884:121).

\section{THE GULNARE EXPEDITION 1880-81}

The opportunity for a polar trip finally materialized for Pavy in 1880, the brainchild of Captain W. Henry Howgate, Chief Disbursing Officer in the U.S. Army Signal Corps, the branch of service tasked with communications and weather forecasting. Officers of the Signal Corps were aware that Arctic systems of Alaska, Greenland, and 
northern Canada had some effect on local weather patterns, and although they were unsure of the extent of such systems, they were considering methods to analyze just how they affected weather patterns within the United States (Howgate, 1878:6).

Howgate had concluded that the best way to conduct scientific observations and exploration in the Arctic was by establishing a temporary "colony" at Lady Franklin Bay in the upper end of Smith Sound, to be manned by Inuit and their families (Howgate, 1878:15-17). Howgate repeatedly petitioned the U.S. Congress for an authorization of $\$ 50000$ (Guttridge, 2000:21-32). Expecting to receive the necessary funding, in August 1877 Howgate assembled and launched an advance party for his main expedition, privately outfitted at a cost of approximately $\$ 10000$. The preliminary expedition spent the winter of $1877-78$ organizing stores and Inuit support in Cumberland Sound on the southern end of Baffin Island (Howgate, 1879).

Delays beset Howgate's follow-up plans, and it was not until 1880 that he could marshal the funds and the governmental support for his proposal to establish a "colony" at Lady Franklin Bay on the Ellesmere Island coast (Barr, 1985:6). Unfortunately, the fate of the expedition was sealed before it even left Washington, D.C., when Howgate purchased a 200-ton sealing steamer, Gulnare, to transport the party to its destination. Overly anxious to proceed with his plan, Howgate neglected to perform a thorough examination of the vessel before committing to its purchase (Scott, 2007:206). Since military personnel were committed to the project, the U.S. government demanded an inspection by a board of naval officers, who immediately condemned the vessel (Barr, 1985:6). As a consequence, the government withdrew its support for the expedition. Howgate was undeterred, and the expedition became his personal quest as he set about to remedy Gulnare's deficiencies.

The expedition's command was initially offered to Lieutenant Adolphus W. Greely with the Signal Corps, but Greely prudently declined after the ship was condemned (Barr, 1985:6). However, two other military men, Lieutenant Gustavus C. Doane, 2nd Cavalry, and Lieutenant Wiliam H. Low, Jr., 20th Infantry, requested leaves of absence from the U.S. Army to serve on the expedition (Scott, 2007:208). Their addition shortly before Gulnare's departure created considerable confusion regarding its command structure. Inspired by explorer-soldier General John C. Fremont, Doane obtained leave over the objections of General William T. Sherman, who declared Doane "a Cavalry officer of too great value to be banished in the Polar Regions" (Doane, 1860-1939, Papers II: 5 May 1880). Low was a highly regarded West Pointer with experience in the Indian wars (Doane, 1881:28). Through a member of the Signal Corps, Octave Pavy was introduced to Howgate and hastily concluded a contract pursuant to which Pavy would serve as expedition naturalist and physician. Howgate was anxious to obtain Pavy's services for the expedition, but unwilling to agree outright to appoint Pavy as commander of the "colony" that Howgate intended to establish at its destination. He placated the ambitious Pavy by telling him that the members of the expedition would select the commander of the so-called "land party," a comment which Pavy took to be an informal promise that he would be granted the command (Pavy, 1880b:4). In truth, Howgate had no intention of awarding Pavy the command because the military men, Doane and Low, could not serve under civilian authority, and Howgate believed that placing military men in the leadership positions would maintain the favorable support of the U.S. Army for the next season (Pavy, 1880b:4-6).

Gulnare departed Fort Monroe on 21 June 1880 with Dr. Pavy on board, but Doane and Low were still in Washington, D.C., planning to join the ship in Halifax (Doane, 1881:12). Just prior to departure, to his utter frustration, Pavy learned that Low would receive command of the land party. Outraged, Pavy communicated his dissatisfaction to Howgate and threatened to leave the expedition in Nova Scotia. The anxious Howgate recruited a replacement surgeon, Dr. Leonard Rohe. Lilla May Pavy, writing to Octave in Nova Scotia, dissuaded the headstrong Pavy from quitting. Even though Howgate had been "slippery" and "underhanded," she advised, Pavy would ruin any future opportunity by walking away (Pavy, 1880b:5-6).

Immediately upon departure, it was discovered that the Gulnare, which was expected to challenge ice floes in some of the most demanding seas of the world, was completely unseaworthy. Worse, on 28 June, off the coast of Nova Scotia, the ship's furnaces overheated and were disabled by a heavy salt buildup that had been carelessly overlooked during its refitting (Doane, 1881:17). In the absence of more senior leadership, Pavy began to exert his influence, persuading the shipmaster, Captain H.C. Palmer, to hoist sail directly for St. John's and to bypass its intended stop in Halifax (Doane, 1860-1939, Papers II: 14 July 1880 telegram). In Halifax, Doane was obviously alarmed by what he viewed as an unjustified action, but Pavy claimed with some truth that heavy fog cover and a lack of steam made the decision unavoidable even if it also bypassed some expedition members that Pavy viewed as unnecessary (Doane, 1881:15, 18). However, having reached St. John's, Pavy continued to exercise control over affairs. In advance of authority from Howgate, he contracted repairs to the malfunctioning boiler locally, at a total price of close to $\$ 5000$, a charge that Doane later labeled as "extravagant" (Doane, 1860 - 1939, Papers II: 14 July 1880 telegram). However, if the expedition was to have any chance of accomplishing its objective within the narrowing window of the remaining season, the repairs were absolutely necessary, and Howgate made good by wiring payment.

But, in Doane's absence, matters were taking a more ominous course. A telegram dispatched to Howgate on 8 July, signed by Pavy, Captain Palmer, and meteorologist O.T. Sherman, demanded that Howgate immediately appoint a leader of the "land party." Pavy coveted this position, but selecting him would clearly be at odds with Low's appointment as commander for that position (Doane, 1860-1939, 


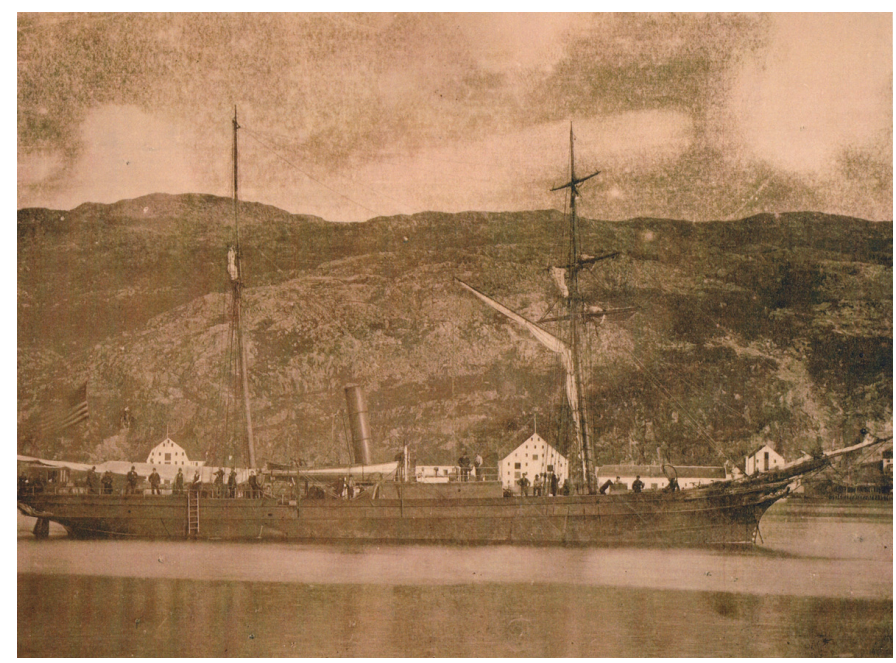

FIG. 6. Gulnare at St. John's, Newfoundland, 1880 (courtesy of the Smithsonian Archives).

Papers II: 8 July 1880 telegram). Incensed by the action and fearful that Pavy might simply leave without him while he was delayed at Halifax, Doane desperately telegraphed Howgate to demand that Pavy remain with the Gulnare in St. John's (Doane, 1860-1939, Papers II: 14 July 1880 telegram). In response, on 15 July, Howgate directed the U.S. consul at St. John's, Thomas N. Malloy, to hold the Gulnare until Doane's arrival on 20 July and informed Molloy that "Pavy has no command." In the meantime, he urged Doane to hurry to St. John's as quickly as possible, adding that if "Pavy gives trouble discharge him" (Doane, 1860-1939, Papers II: 15 July 1880 telegram).

Pavy had accepted Lilla May's advice to remain with the expedition, but now had to deal with Howgate's replacement physician, Dr. Leonard Rohe, who had arrived in St. John's. A heated dispute arose over their relative positions, since each believed he held the post of surgeon, and Pavy leveled some particularly stinging personal comments at Rohe (Doane, 1881:34, 27 July 1880 letter). Doane, now also in St. John's, stepped in to break the deadlock, and in deference to Pavy, recommended that Rohe serve as a volunteer and not as surgeon. Thoroughly insulted by Pavy's conduct and not willing to accept an apology from Pavy, Rohe left the expedition at St. John's (Doane, 1881:33, 27 July 1880 letter). The entire affair highlighted some of Pavy's most negative traits: an unwillingness to accept orders and a tendency to overstep his authority. As importantly, Pavy's personality also reflected what one acquaintance, Sergeant J.H. Weber of the Signal Corps, referred to as "a nervous temperament" (Weber, 1883). He was easily provoked when matters were not to his liking and could become so meanspirited as to completely undermine constructive interpersonal relationships.

As the Gulnare continued to Godhavn (Qeqertarsuaq), Greenland, the full extent of the ship's shortcomings was exposed (Fig. 6). Doane was advised by whalers that the ice in Davis Strait had been particularly heavy that year. With the utter unfitness of the ship, a shortage of coal, and an unfavorable turn in the weather, Doane had the sense to realize that it would be folly to sail for Lady Franklin Bay. It was obvious to Pavy that the more cautious Doane would never commit the decrepit Gulnare to the ice or even chance an overwintering. Frustrated with the disappointing course of events, Pavy decided to make his own plans and informed Howgate, in a rather hostile tone, of his decision to remain in Greenland:

By the fragmentary facts of this letter you can see that the expedition is destined to be back by next Fall, and will not even take one chance of being caught in the ice. But, Octave Pavy will not return, and any one that supposes I took this subject for a toy, or this trip for a pleasure trip, is very much mistaken. I made sacrifices to undertake it, and I shall endure many sacrifices to accomplish it. I should not for a moment allow personal feelings to deter me from such an ambition and I leave you to judge how little ignorance and cowardice will be likely to influence me.

(copy recorded in Pavy, 1880: July 1880).

After what Pavy characterized as a "long bitter battle," he persuaded the departing Doane to leave him, along with another volunteer, Henry "Harry" Clay (grandson of the famous Kentucky statesman of the same name), at the tiny settlement of Rittenbenk, on the far end Disko Island, 45 miles from Godhavn, with all the provisions Doane could supply (Doane, 1881:80) (Fig. 7). Although Doane was prepared simply to abort the project, Pavy's action at least preserved the spirit of Howgate's original plan and salvaged some benefit for the following year's attempt. Pavy's own ambitious (and perhaps improbable) plan was to winter at Rittenbenk, and in the following spring, make a run for Port Foulke, Hayes's winter harbor in Smith Sound, and then travel as far north as possible to Lady Franklin Bay or Thank God Harbor (the winter quarters for Hall's Polaris expedition in 1870-71), laying depots along the way. Pavy envisioned an attempt to reach Cape Joseph Henry, on the northern coast of Ellesmere Island, in order to confirm the existence of "paleocrystic" ice (or multiyear ice) encountered by the British Arctic Expedition of 1875-76 under the command of Captain George S. Nares (Pavy, 1881; Nares, 1878, Vol. 1:361).

Despite his enthusiasm for Arctic work, Pavy suffered from a lack of attention to detail and routine. The personal diary he kept sporadically during his stay in Greenland is filled with occasional references to local events and medical services rendered, as well as criticism of Howgate's conduct and repeated musings on his own disappointment and anger (Pavy, 1880c:Files 6-15). His scientific observations appear to have been lost or were simply non-existent. Although Pavy had difficulty at times working constructively with others (mainly superiors), he was open-minded and willing to listen when it came to learning the basic skills necessary for Arctic survival and travel from those who were more knowledgeable from practical experience. 


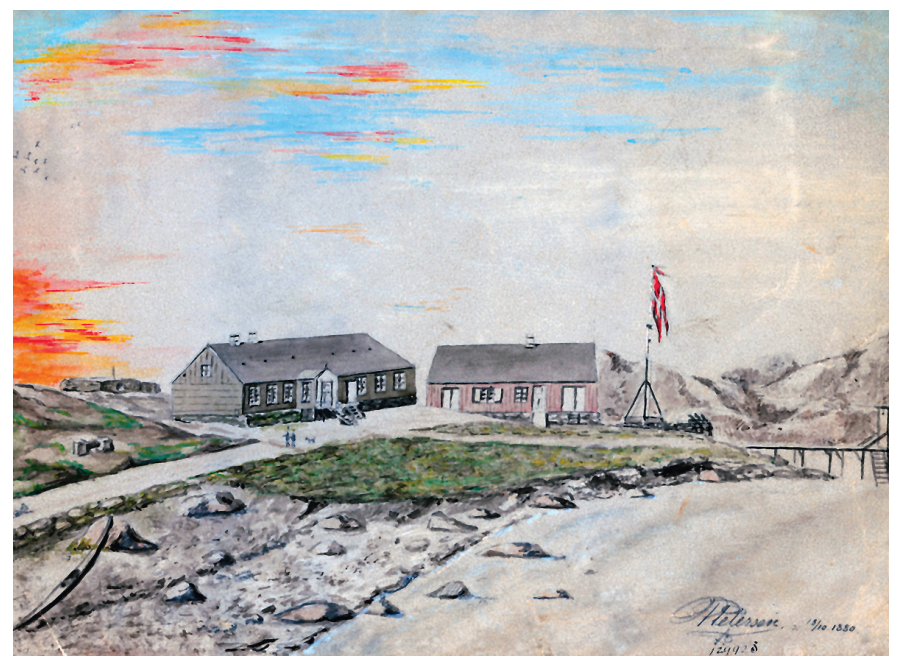

FIG. 7. Sketch by H. Petersen of the settlement at Rittenbenk, sent by Octave Pavy to Lilla May Pavy (courtesy of the Smithsonian Archives).

Pavy accompanied Mr. Krarup Smith, Royal Inspector of North Greenland, on his regular tour of the settlements along the Greenland coast. He worked hard to learn the basics of the Inuit language (which he felt was "indispensable" in the North) and acquired Inuit knowledge, including how to use dog teams for effective Arctic journeying and erect snow huts for sleeping, as well as the skills needed for successful hunting in the North (Pavy, 1881). He prided himself on having fully adopted the Inuit lifestyle. His longest sledge excursion was a circuitous 750-mile round trip from Godhavn to Upernavik (Kalaallisut) with 18 dogs and one Inuk, a grueling trip during which he fell through the ice and was badly frostbitten (Pavy, 1882). Pavy also tasked himself with collecting as much material support as possible on behalf of the expedition expected in the following year. It was a personal commitment that he more than met. Pavy managed to muster a number of serviceable dogs, a quantity of Arctic clothing, as well as a large amount of dried fish and meat, all important additions in support of the Greely expedition (Greely, 1888, Vol. I:3). He also boasted that through his own example, he had so "won the friendship and confidence of the Esquimaux" that he could readily recruit any number of them to join the expedition (Pavy, 1882). Two of them did so, Jens Edwards and Frederik Thorlip Christiansen, and they became vital contributors. By the time that Greely arrived in Disko the following summer, Pavy was also the most experienced member of the expedition besides Edwards and Christiansen, a fact that no doubt contributed to his belief in his own superiority on Arctic matters when dealing with his commander.

In Disko, however, Pavy's headstrong attitude led to another complete falling out with his only other expedition member, Henry Clay. The bad blood between the two led them to maintain separate lodgings as far apart from one another as possible in the small settlement. According to Clay, the disagreement had been brought on, in part, by Pavy's refusal to care for a child who was badly in need of medical care while Pavy and Clay were visiting
Uummannaq, a village north of Rittenbenk on the Greenland coast (Apple, 1997:20). The father of the child was Mr. Moldrup (perhaps K.M. Moldrup, an assistant in the Greenland Trade Service). While in Uummannaq, Pavy did his best to treat the child, whose recurring fevers were a continuing cause of concern for the worried parents. According to Clay, as the days dragged on, Pavy chose to discontinue treatment rather than face the distraught parents, who were pressing him to do more. Ultimately, the poor child died.

Clay was so upset over the matter that he never forgave Pavy for what he viewed as Pavy's dishonorable conduct in not continuing his treatment of the child. In a speech delivered upon his return to Louisville, Clay left no doubt about his belief in Pavy's misplaced priorities, remarking that: "He [Pavy] is an enthusiast, almost a monomaniac, upon the subject of Arctic exploration, and to discover the North Pole, he would sacrifice everything he has on earthfriends, home, wife, life itself-he would consign his soul to perdition, if he believed in perdition" (Apple, 1997:21). Clay's negative assessment of Pavy's conduct and character was not, however, the only firsthand opinion circulating in Greenland. Curiously, on Pavy's departure from Rittenbenk, Inspector Krarup Smith penned an effusive parting letter of commendation, perhaps at Pavy's behest, but nonetheless reflecting a heartfelt thanks for Pavy's services: "I wish...to acknowledge the great and never tired attention, which you during your stay here in North Greenland always and everywhere have paid us here, be it the Danes or be it the natives, in medical respects" (Smith, 1881). Smith was also impressed with the level of Pavy's Arctic skills, remarking that "very few men are so well fit for traveling in polar regions as you [Pavy]." Smith closed with a cautionary note, however, observantly opining that "Americans commonly underrate the difficulties and obstacles in the real polar, paleocrystic sea and along its coasts" (Smith, 1881).

Back in the United States, Lilla May Pavy was proving to be a more tactful personality and more astute in the art of diplomacy. She willingly accepted Octave Pavy's single-minded pursuit of the Pole and became an outspoken advocate on his behalf. Quickly realizing that gaining access to Washington society and fostering personal relationships could advance her husband's cause, she cultivated close friendships with both Henrietta Greely (wife of Adolphus Greely) and Bessie Howgate (wife of Henry Howgate). She became especially close with Mrs. Howgate, a woman who had few friends in Washington and suffered from her husband's very public womanizing. Lilla May's lobbying of Greely was evidently producing some positive results, as she confided in her diary her opinion that "he [Greely] would select you [Pavy] as the leading commander of the ice party and I think he is in favor of you as Surgeon and Land commander. I hope this will be the case and I have been doing everything I could to gain their favor for you and myself leading to your benefit in the end" (Pavy, 1880). Recognizing that a book of Pavy's Gulnare adventures could bolster his reputation, Lilla May pressed Pavy to 
record a narrative of his adventures even if he could manage to do so only in French. From her meager salary as a government clerk, she paid for a French tutor for herself to prepare a translation of Pavy's work (Pavy, 1880).

Octave's proficiency in written English was limited, but Lilla May, the English teacher, was a master of the written word, and in Octave's absence, acted as his local agent, writing at length to Charles Daly at the American Geographical Society and the French Consul at St. John's seeking funding to continue his Arctic researches in case further government funding was not available. Through connections at the St. Louis Globe-Democrat, she managed to publish accounts of Pavy's activities in Greenland and his appeals for further government support (Pavy, 1881, 1882). Also, having established connections through the music lessons she provided to children of Washington politicians, she petitioned select members of the House and Senate and the Navy Department.

When the Gulnare finally returned to Washington on 8 October 1880, it was with mixed emotions that Lilla May Pavy was present to meet the returning members of the expedition knowing that her husband would not be among them. George Rice, the expedition's photographer, provided her with some welcome news about Octave and his health and activities. Rice's opinion of Pavy, which he openly shared with Lilla May, reflected the profoundly contrasting aspects of Pavy's personality. Although he could be maintained in high regard, and even well liked, by many of his comrades, at the same time he could have appalling relationships with others. Contrary to the disastrous falling out with Clay, Rice reported to Lilla May that Octave was "loved" by all on board the Gulnare and "for no one would they run to do a favor quicker than him [Pavy]" (Pavy, 1880). Even Lieutenant Doane, his commanding officer, who had his share of disagreements with Pavy, still found Pavy to be a qualified physician and "of most charming manners," and he fully respected Pavy's decision to remain in Rittenbenk (Doane, 1881:80). Doane believed that the professionalism and enthusiasm that Pavy applied to the "Arctic question" would lead to worthwhile results.

\section{LADY FRANKLIN BAY EXPEDITION 1881-84}

The U.S. government had finally managed to place its support behind another expedition to Lady Franklin Bay, when international polar interest culminated in the scientific program known as the First International Polar Year. The concept of international cooperation in the polar regions had originated with the scientist Karl Weyprecht, who believed that simultaneous scientific observations from multiple locations would produce more meaningful results and foster a spirit of cooperation rather than competition in the Arctic (Barr, 1985:2-3). As a result of Weyprecht's efforts, 11 nations established research locations in the Arctic as part of the First International Polar Year. The U.S. International Polar Year Expedition 1881-84, otherwise known as the Lady Franklin Bay Expedition or Greely expedition, was one of two expeditions supported by the United States to further Weyprecht's objective (the other was stationed at Point Barrow, Alaska) (Greely, 1888, Vol. I:1). The Greely expedition was commanded by Lieutenant Adolphus W. Greely of the U.S. Army Signal Corps and comprised 25 members, drawn largely from the U.S. Army (Greely, 1886, Vol. I: ix-xi). Its location at Lady Franklin Bay (Fort Conger), along the Ellesmere Island coast was chosen as a result of the previous wintering near that location in 1875-76 by the British Arctic Expedition (Barr, 1985:6-7).

On 20 July 1881, the Greely Expedition transport ship, Proteus, arrived in the village of Godhavn on the west coast of Greenland to gather supplies and to take on board Octave Pavy and Henry Clay, still present from the failed Gulnare expedition the year before. Pavy was offered the position of Acting Assistant Surgeon, U.S. Army, and Clay that of Signal Service employee (Greely, 1888, Vol. I:3). Pavy's short temper and combative personality certainly made him a poor choice for an expedition whose members would spend at least two years in close quarters under rigid military discipline. Unfortunately for Greely, the individual in the best position to apprise him of Pavy's shortcomings, Henry Howgate, had long before departed the Signal Corps under shady circumstances. In December 1880, Howgate had resigned his position following the discovery that he had embezzled more than $\$ 100000$ from the Signal Corps, some of which may have been used to purchase the Gulnare (Anon., 1881b). However, Greely soon had his own opportunity to assess Pavy's character and to witness his headstrong disposition firstand. The Proteus proceeded to Lady Franklin Bay, where the expedition members disembarked and settled in for the winter, occupied with procuring food and preparing for spring sledge journeys. The personality clash between Pavy and Clay from the preceding winter continued unabated. On 14 August, the quarrelsome Pavy delivered a blunt ultimatum to his new commanding officer: unless Clay was removed from the expedition, Pavy would leave it. Greely found it "trying in the extreme" that a subordinate under military command should be dictating orders to his commander, but he also realized that having a physician was of vital importance (Greely, 1888, Vol. I:7). Graciously, the more balanced Clay stepped in to break the deadlock by tendering his resignation to Greely and departing with the Proteus on 19 August 1881.

Pavy's contractual responsibilities as a physician required him to acquaint himself with the physical condition of the crew and to undertake his prescribed medical duties, which included maintaining a proper diet that would hold scurvy at bay. Pavy performed those duties laudably throughout the expedition for which Greely was rightly complimentary (Greely, 1888, Vol. I:362). Although the relationship between Pavy and Greely was strained even from the start, Greely also recognized that Pavy's practical experience in Arctic travel, coupled with his driving ambition, made him a valuable member of an expedition 
composed of military men recruited from frontier outposts of the American West. On 29 August 1881, Pavy, accompanied by the expedition photographer, Sergeant George W. Rice (who had previously sailed with the Gulnare expedition), undertook his first journey, an overland trek of 10 days towards Cape Joseph Henry along the northeastern coast of Ellesmere Island, to scout a potential route to the north for the subsequent sledge journeys and to search for signs of the lost Jeannette expedition (Greely, 1888, Vol. $\mathrm{I}: 121-122)$.

Pavy's interest in Cape Joseph Henry is not surprising, as he undoubtedly knew that this location had been the launching point for the record high northern latitude, the so-called "Farthest North," achieved on 12 May 1876 by Lieutenant A.H. Markham of the British Arctic Expedition of 1875-76 (Markham, 1878:348-349). Although Pavy's party was unable to reach Cape Joseph Henry because of ice conditions, Pavy's medical skills were put to the test on the return, when Rice fell seriously ill with acute rheumatism. Pavy tended ably to his ailing companion, carrying his load for miles and finally pushing on solo to obtain help (Lotz, 2009:34-35). In October and November, the enthusiastic Pavy completed two follow-up excursions using dogs in the vicinity of Cape Joseph Henry, which he maintained was the most favorable approach for an attempt on the "Farthest North" (Greely, 1888, Vol. I:131-133, 139-142). Pavy's traveling companion for one of these trips, Private William Whisler, confided to Greely and Sergeant David Brainard that Pavy, in contrast to the commendable service he had given to ailing Sergeant Rice, this time had displayed more dastardly conduct while on the trail. Pavy had solicited Whisler for his planned "Farthest North" attempt the following spring and proposed stealing the expedition's best dog team from Lieutenant James Booth Lockwood, an act that would have forestalled Lockwood's own "Farthest North" attempt. When Whisler declined to participate in the scheme, Pavy became openly abusive toward him, so much so that Whisler could only settle the recalcitrant Pavy by drawing his revolver (Brainard, 1929:230-231).

Through the long, dark winter, the resentment between the commander and the doctor continued to fester, but Pavy continued to demonstrate that he was an effective physician, treating a number of maladies, including the most severe, the broken leg of Sergeant Hampden Gardiner, which immobilized him for three months (Greely, 1886, Vol. I:166). However, Pavy's geographical opinions also continued to carry weight with his commander and when Pavy insisted, on the basis of his previous journeys, that a northern route could still be advanced from Cape Joseph Henry, Greely permitted him to test his theory, even offering his own dog team in support (Fig. 8) (Pavy, 1888:166-178). On 19 March 1882, Pavy, Jens Edwards, and George Rice left Fort Conger with two sleds and nine dogs. By 28 March, they had reached only as far as Cape Union, where they were stymied by ice along the Ellesmere Island coast. From a latitude north of where William Morton, on the expedition of Elisha Kent Kane, claimed to have seen an open

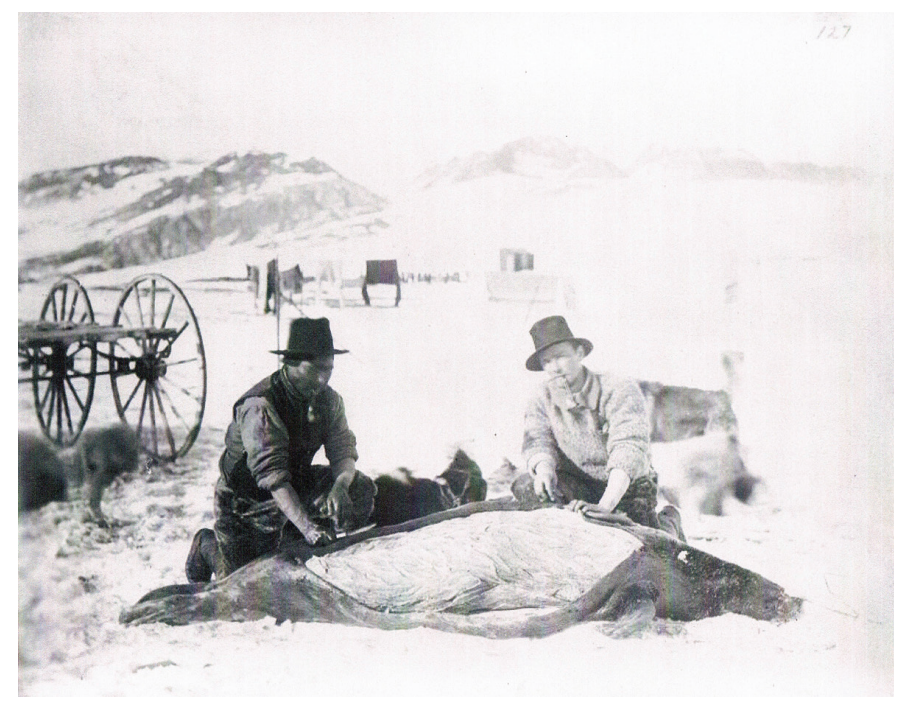

FIG. 8. Octave Pavy and Jens Edwards skinning a seal (Greely, 1886, Vol. II:256).

polar sea in August 1854, Pavy viewed the upper reaches of Smith South along the Greenland coast. However, the hoped-for view of the expanse of open water so visible to his predecessors was not what now faced Pavy:

To the south the faint outline of Cape Constitution evoked reminiscences of "The good Christian knight, Elijah Kent Kane," and set my mind pondering over the now old and nearly forgotten fable of an Open Polar Sea. I was standing on the extreme point reached by the poetical vision of Hayes, at the threshold of a once great mystery, that in younger days had so profoundly moved my imagination. Instead of a promised sea I could view nothing but the stern and cold reality of an impenetrable ice pack.

(Pavy, 1888:169)

Once a firm armchair believer in the open polar sea, Pavy now just as firmly denied its existence. After nearly being set adrift in the broken ice as they neared Cape Joseph Henry, the party scrambled back to the safety of land, and their brief excursion ended on 2 May 1882. Although the trip did not accomplish its main objective, Pavy had completed a six-week sledge journey of 300 miles by dog sled across some of the most difficult conditions in the North and returned with his party in good health. However, the affair only confirmed Greely's opinion that the northern coast of Greenland was a better avenue for achieving a "Farthest North." On 13 May 1882, a party under the command of Lieutenant James Booth Lockwood did manage to better Markham's "Farthest North" by only a few miles, marking the highlight of the Greely expedition's geographical achievements (Greely, 1886, Vol. I:335). Pavy attributed this accomplishment to his own successful efforts in gathering dogs while in Greenland before Greely's arrival.

Having lived and worked with the Inuit for more than a year, however, Pavy had also come to understand and 
respect their unique skills far more than his commander did. While Greely had a negative opinion of Inuit sledge drivers, the observant Pavy recognized the valuable assistance they could provide in sledge travel in the Smith Sound region. In his official report Pavy noted those advantages:

The [Inuit] are indispensable for extended sledge journeys. Their experience in managing dogs, and the apparent facility with which they can drive at once over difficulties where the best of their inexperienced Caucasian pupils will fail, or labor for long hours, put the usefulness of their services out of the question. Moreover, their endurance to cold will allow them to perform the many duties of a driver with bare hands, and in half of the time that it would take to freeze ours.

The history of the Arctic work, from Wrangel to this day, will bear witness to the fact that all dog sledging expeditions that have used natives as drivers, or perhaps their best substitutes (I mean men trained for years to the work), have succeeded with comparative ease.

(Pavy, 1888:168).

The summer concluded with additional scientific and geographical accomplishments, including the exploration of the Lake Hazen region. Pavy's one-year contract, which had expired on 20 July 1882, was renewed by mutual agreement between Pavy and Greely (Greely, 1886, Vol. I:418). Nonetheless, their relationship only deteriorated further: there was no end to Greely's faultfinding with Pavy, but some of those criticisms were legitimate. The responsibility for cataloging the expedition's extensive natural history collection was transferred to Lockwood when Pavy simply lost interest in it, continuing a lack of attention to detail first evident during his Gulnare experience (Greely, 1888, Vol. I:298). Pavy even became delinquent in reporting on the medical condition of the men. Greely aptly summarized his blunt opinion of Pavy's incorrigible character in his Three Years of Arctic Service, published in 1886: Pavy's "previous Bohemian life made any restraint irksome and subordination to military authority particularly obnoxious" (Greely, 1886, Vol. II:62). However, as in the circumstances of the Gulnare expedition, contrasting opinions were also evident. Although Pavy could display a particularly quarrelsome attitude toward his commanding officer, he could continue to command the respect of most of the men with whom he served for both the favorable aspects of his personality and the merit of his skills. Sergeant David Brainard, Greely's second-in-command, shared that mixed opinion of Pavy, and believed Pavy and Greely were equally at fault for their poor relationship. Perhaps Brainard's assessment of the two competing personalities was the more accurate when he noted that "between the cosmopolitan bohemian and the New England puritan, the difference in temperaments had been too great" (Brainard, 1929:33).

As the second winter passed without the arrival of a relief ship, Pavy was becoming uneasy about their circumstances. After re-reading the history of the Franklin disaster on a dark, cold and forbidding evening in January 1883, he contemplated whether the members of the Greely expedition were destined to share the same fate (Pavy, 1881-84:544). He began to urge Greely to consider making plans to retreat southward (Pavy, 1886b:374-376) and suggested that a scouting party (or the entire expedition) be dispatched south to Littleton Island to establish a potential line of communication with the absent relief parties (Pavy, 1881-84:368; Pavy, 1886a:263). Pavy pointed specifically to the experience of Sir Robert McClure, whose expedition was saved from disaster in 1853 when a written message left by McClure's men and recovered by a searching party led to McClure's rescue (Pavy, 1881-84:368). Greely, however, had come to resent the opinions of his medical officer so much that he simply ignored them. He rejected Pavy's southward rescue proposal, as well as his suggestion to minimize early-season sledging activities for discovery purposes in the second year to avoid weakening the men's long-term health in advance of the expected retreat from Fort Conger. Pavy had made this suggestion after recognizing how badly the sledge expeditions had suffered in the second year of the British Arctic Expedition 1875-76 even though the men were apparently in good health when they started (Pavy, 1881-84:455-456, 528).

In July 1883, when his contract was expiring, Pavy refused to renew the arrangement, blaming his commander for a litany of perceived failures (Greely, 1888, Vol. I:48). However, true to his oath, Pavy continued his professional responsibilities as physician. He had made a careful study of his Arctic predecessors and his diary reflects forwardlooking opinions on the well-being of the expedition based on these prior experiences. The well-read Pavy was fully aware of the importance of a fresh food diet after two years in the Arctic (Pavy, 1881-84:143-144). Anxious to avoid the difficulties suffered by the British Arctic Expedition of $1875-76$, which succumbed to an outbreak of scurvy after its first year, Pavy was fastidious about maintaining a diet of fresh meat. His diary reflects the close scrutiny he paid to early symptoms of scurvy, such as swelling of the gums, and the prompt treatment he meted out when faced with potential outbreaks (Pavy, 1881-84:348, 376).

Matters with Greely boiled over after Pavy's resignation from the expedition, when Greely ordered Pavy to turn over his diary, likely the last thing Pavy wanted Greely to see. When Pavy refused, Greely had him placed under arrest and subject to court-martial. Recognizing the absurdity of their situation, reminiscent of William Godfrey's "arrest" by Elisha Kent Kane during his expedition of 1853-55, Greely relented and permitted Pavy freedom to wander within the camp (Greely, 1886, Vol. II:66).

The Greely expedition's long awaited retreat several hundred miles south to Cape Sabine along the west side of Smith Sound began in earnest on 9 August 1883 by means of the steam launch, named Lady Greely after the commander's wife. The difficult trip managed to tax the tenuous relationship closer to the breaking point. On the evening of 20 August, Pavy in hushed tones raised a plan with certain 
members for a mutiny. According to Brainard, if Greely should order them to abandon the launch and try their fate among the floes, Pavy would declare the commander unfit and relieve him of duty (Brainard, 1929:52). Although the attempt never materialized, it showed how far at odds Pavy was with his commander, yet evidently Pavy had the support of both Sergeant Rice and Lieutenant Frederick F. Kislingbury (Brainard, 1929:52).

They arrived on 30 September 1883 at Camp Clay, named by Greely after Pavy's now absent companion from the Gulnare expedition. The circumstances of the miserable stay at Camp Clay have been documented in full detail by numerous researchers (e.g., Todd, 1961; Guttridge, 2000). Over the course of the next nine months, 18 expedition members slowly died, and allegations of food theft abounded as their meagre stores were exhausted. Among the more disturbing acts confirmed by Greely was Pavy's theft of food from Corporal Joseph Elison, an invalid wholly dependent upon Pavy's care. Shocking though it was, Greely chose to ignore the misconduct rather than confront the physician when his medical services were so absolutely necessary (Greely, 1886, Vol. II:207). Certainly Pavy had his hands full with all sorts of physical maladies, which were complicated by the lack of food and weakened state of the men's health. Oddly, in the midst of this misery, as if to counter any potential future criticisms, Pavy circulated a testimonial praising his medical skills during the entire expedition, which the 13 members then remaining were pleased to sign in acknowledgement (Greely, 1888, Vol. I:362). Greely was not one of them, however, and the relations between the commander and the doctor deteriorated even further. On 6 May, as the two argued over the condition of one of Pavy's reports, an infuriated Greely exclaimed that "If you [Pavy] were not the Surgeon of this Expedition I would shoot you!" (Brainard, 1929:261). At 2 p.m. on 6 June, Private Charles Henry was executed for stealing food. Octave Pavy died at 6 p.m. the same day (Brainard, 1929:290). According to Greely, the doctor's death was caused by a self-administered overdose of a poisonous medicine (ergot) (Greely, 1886, Vol. II:320). The men being too weak to dig a proper grave, Pavy's body was plunged into a tidal crack on 9 June and carried out to sea.

On 22 June 1884, the hoped-for relief expedition finally arrived. Only seven men remained alive, one of whom (Ellison) died shortly thereafter (Schley and Soley, 1885:220, 261). On 18 July, the despondent Lilla May Pavy was informed of Octave Pavy's death, and she took it badly (Anon., 1884b). During their six years of marriage, Pavy had been absent in the Arctic for four years. Upon Greely's return, he had to deal with the circumstances surrounding the execution of Private Henry, as well as rumors of cannibalism. Although the cannibalism charges ultimately subsided, the wrath of Lilla May Pavy only swelled, and she continued to press Greely for more information about the circumstances of her husband's death and for his papers. For a time, she even contemplated traveling to Greenland to obtain more details (Anon., 1885). After Greely published his Three Years of Arctic Service, she published several articles to counter what she believed were negative statements about her husband and to defend his character (Pavy, 1886a, b). For herself, Lilla May also pushed for Pavy's back pay and a pension, which she was not entitled to as a matter of right since after his resignation, Pavy was considered a civilian.

However, Lilla May had problems of her own to deal with as she sought to settle the estate of Octave Pavy. Pavy's death served as the impetus for a claim by his illegitimate daughter in Paris for a share of his estate, namely a claim to Pavy's back pay and the pension that Lilla May was seeking from the government. The daughter, Berthe Pavy, was born on 4 July 1869 in Paris (Anon., 1886a). Evidently, Octave had become intimately acquainted with her mother, Teresa L'Oiseau, while a student in medical school. Teresa (now assuming the surname of Pavy after his death) claimed that Octave Pavy's father would not consent to their marriage, but that Octave acknowledged the affair and his moral obligation to care for the child (Anon., 1886a). Much to Berthe's disappointment, neither Octave nor Pierre Pavy honored the commitment, so she was compelled to retain a lawyer to pursue her claim against Pavy's estate. After a persistent two-year campaign, Lilla May Pavy was awarded Pavy's back pay and a monthly pension by an appropriation under an Act of the U.S. Congress, which in effect also precluded any other claimants to the money through Pavy's estate (Anon., 1886b). Berthe Pavy was not left destitute, however, as the Société de Géographie in Paris furnished her a large contribution in recognition of Pavy's French allegiance (Todd, 1961:303). The scandalous affair made for lively press coverage in the St. Louis Globe-Democrat by an eager reporter who doggedly unearthed the sordid details (Anon., 1886a). Physically and emotionally weary, Lilla May retreated to Europe for a year to regain her health (Anon., 1888). Little was heard of her again until her remarriage to a gentleman named Homer M. Case in Omaha, Nebraska, in July 1891 (Anon., 1891).

\section{CONCLUSION}

Dr. Octave Pavy was a complicated figure with a highly temperamental personality. He was often a quarrelsome malcontent unwilling to accept authority, most notably when serving under Lieutenant Adolphus W. Greely. Those shortcomings have overshadowed any positive contributions on Pavy's part. Through his own efforts, over a period of many years and failed Arctic attempts, Pavy became a knowledgeable and experienced Arctic traveler. However, his contributions extended beyond his own survival and travel skills. Besides undertaking exploratory and support sledge journeys on behalf of the Greely expedition, Pavy doggedly and single-handedly executed the basic purpose of the overlooked and ill-fated Gulnare expedition, supporting the Greely expedition not only with necessary dogs, food, and supplies, but also through the addition of two of 
its most competent members, Jens Edwards and Frederik Christianson. During the course of the Gulnare expedition, while in Disko, Greenland, and largely throughout the harrowing Greely expedition, under exceptionally trying circumstances, Pavy demonstrated that he was a competent physician who took great interest in the well-being of his patients and largely performed his medical duties to the highest standards. In this role, he gained the respect of his peers.

\section{REFERENCES}

Anon. 1868. News. Boston Daily Advertiser, April 22.

1869. Affairs in France. Ascension of the Monster

Balloon. The New York Times, July 19.

. 1871. La Guérille Noire. The Graphic, January 28.

. 1872a. A cool subject. The New York Times, June 23.

. 1872b. Has Pavy gone to the Pole? The Sun, December 17.

1881b. Howgate's hearing delayed. The New York Times,

August 21.

- 1884a. The late Dr. Octave Pavy. St. Louis Daily Globe-

Democrat, July 20.

- 1884b. Mrs. Pavy gets the news. National Republican,

July 19 .

1885. Personal and impersonal. Abilene Reflector, May 7.

1886a. An Arctic romance. St. Louis Daily Globe-

Democrat, October 12.

- 1886b. In favor of the widow. The Salt Lake Herald, September 30 .

—. 1888. Lincoln County Tribune, June 2.

http://chroniclingamerica.loc.gov/lccn/2010270502/1888-06-

02/ed-1/seq-4/

1891. Miscellaneous. The Red Cloud Chief, July 17.

Apple, L. 1997. In search of a star: A Kentucky Clay goes to the Arctic. The Filson Club History Quarterly 71(1):3-26.

Barr, W. 1985. The expeditions of the first International Polar Year, 1882-83. Technical Paper 29. Calgary, Alberta: The Arctic Institute of North America.

Bent, S. 1857. The Japanese Gulf Stream. Bulletin of the American Geographical and Statistical Society 2:203-213.

Brainard, D.L. 1929. The outpost of the lost: An Arctic adventure. Indianapolis, Indiana: The Bobbs-Merrill Company.

Daly, C.P. 1870. Annual address, by the Hon. Charles P. Daly, President, delivered January 25, 1870. Journal of the American Geographical and Statistical Society 2, pt. 2: 1xxxiii-cxxvi.

- 1873. Report of the reception, by the American Geographical Society, of Captain Hall and his officers, previous to their departure to the Arctic regions, held June 26th, 1871. Journal of the American Geographical Society 3:401-415.

Davidson, G. 1872. In: Notes. The American Naturalist 6(9):570-575.

http://dx.doi.org/10.1086/271006

Doane, G.C. 1860 - 1939. Doane Papers I and II. Collection 2211, Gustavus C. Doane Papers, 1860 - 1939. Papers I: Series 2, Box 2, File 17; Papers II: Series 5, Box 6, File 12. Bozeman: Merrill G. Burlingame Special Collections, The Libraries, Montana State University.
. 1881. Preliminary Report of "Howgate Arctic Expedition" of 1880 by Lieutenant Gustavas C. Doane March 16, 1881. Collection 851, Fort Ellis and Gustavas C. Doane Collection, 1865-1930, Box 1, Folder 1, Howgate Arctic Expedition. Bozeman: Merrill G. Burlingame Special Collections, The Libraries, Montana State University.

Greely, A.W. 1886. Three years of Arctic service: An account of the Lady Franklin Bay Expedition of 1881-84 and the attainment of the farthest North. 2 vols. New York: Charles Scribner's Sons.

- 1888. International Polar Expedition. Report on the proceedings of the United States Expedition to Lady Franklin Bay, Grinnell Land. 2 vols. Washington, D.C.: Government Printing Office.

Guttridge, L.F. 1987. Icebound: The Jeannette expedition's quest for the North Pole. Shrewsbury, United Kingdom: Airlife Publishing Ltd.

- 2000. Ghosts of Cape Sabine: The harrowing true story of the Greely expedition. New York: G.P. Putnam's Sons.

Hayes, I.I. 1867. The open polar sea: A narrative of a voyage of discovery towards the North Pole in the schooner "United States." London: Sampson Low, Son, and Marston.

Holland, C. 1994. Arctic exploration and development c. 500 B.C. to 1915: An encyclopedia. New York and London: Garland Publishing, Inc.

Howgate, H.W. 1878. Polar colonization. Memorial to Congress and Action of Scientific and Commercial Associations. Washington, D.C.

https://archive.org/details/cihm_07025

- ed. 1879. The cruise of the Florence; or Extracts from the journal of the preliminary Arctic expedition of $1877-{ }^{-} 78$. Washington, D.C.: James J. Chapman.

Inglefield, E. 1853. A summer search for Sir John Franklin; with a peep into the Polar Basin. London: Thomas Harrison.

Kane, E.K. 1856. Arctic explorations: The Second Grinnell expedition in search of Sir John Franklin, 1853, '54 and '55. 2 vols. Philadelphia: Childs and Peterson.

Lambert, G. 1867. L'expédition au Pôle Nord. Bulletin de la Société de Géographie 14(Ser. 5):561 -694.

Liégard, M. 1870. Occasional notes. The Paul Mall Gazette, July 19.

Lotz, J. 2009. Canada's forgotten hero: George Rice and the Lady Franklin Bay Expedition, 1881 -84. Wreck Cove, Cape Breton, Nova Scotia: Breton Books.

Markham, A.H. 1878. The great frozen sea: A personal narrative of the voyage of the "Alert" during the Arctic Expedition of 1875-6. London: Daldy, Isbister and Co.

Nares, G.S. 1878. Narrative of a voyage to the polar sea during 1875-76, in H.M. ships 'Alert' and 'Discovery.' 2 vols. London: Sampson Low, Marston, Searle, \& Rivington.

Osborn, S. 1864-65. On the exploration of the North Polar region. Proceedings of the Royal Geographical Society 9:42-58.

Pavy, L.M. 1880. Unpubl. diary and notes, July 1880-February 20, 1881. Author's collection.

1884. Octave P. Pavy. The Dental Advertiser 15(4):115-124. 
1886a. Dr. Pavy and the Polar expedition. The North American Review 142(352):258-269.

ed. 1886b. An Arctic journal. The North American Review 142(353):371-380.

Pavy, O. 1866. Reference AN/AJ/16/8179. Pierrefitte-sur-Seine: Archives nationales. Department Education, Culture et Affaires sociales.

1868. Les nouvelles expéditions au Pôle Nord. Revue Des Deux Mondes September/October 77(2nd per.): 213-226. Translated in October 1868 in: The new expeditions to the North Pole. Littell's Living Age 99(1274):305-310. 1880a. The Polar region. St. Louis Globe-Democrat, February 15.

- 1880b. Letter from Mrs. L.M. Pavy to Dr. Pavy, n.d. Collection of the Lady Franklin Bay Expedition 1881-84, Series I, Box 1, File 20. New York: Explorers Club. 1880c. Notes of Octave Pavy in French and English. Collection of the Lady Franklin Bay Expedition 1881-84, Series I, Box 1, Files 6-16. New York: Explorers Club. 1881. The Paleocrystic sea which Dr. Pavy, formerly of St. Louis, is searching for: His greetings from Greenland's icy mountains. St. Louis Globe-Democrat, January 16. 1881-84. Diary of Octave Pavy (English translation). Records of the Lady Franklin Bay Expedition. Record Group 27.4.5. Washington, D.C.: U.S. National Archives.
1882. A voice from the Arctic: Tidings from the Polar Exploring Colony in Latitude 81 Deg., 44 Min. St. Louis Globe-Democrat, January 2.

- 1888. Dr. Pavy's report on journey northward over Polar Ocean. Appendix No. 47. In: Greely, A.W. International Polar Expedition. Report on the Proceedings of the United States Expedition to Lady Franklin Bay, Grinnell Land, Volume I. Washington, D.C.: Government Printing Office. 166-178.

Petermann, A. 1864-65. On the proposed expedition to the North Pole: A letter addressed to Sir Roderick I. Murchison, K.C.B., by Augustus Petermann, Hon. Corr. Mem. R.G.S., Gotha. Proceedings of the Royal Geographical Society 9:91.

Schley, W.S., and Soley, J.R. 1885. The rescue of Greely. New York: Charles Scribner's Sons.

Scott, K.A. 2007. Yellowstone denied: The life of Gustavus Cheyney Doane. Norman: Oklahoma University Press.

Smith, K. 1881. Letter to Dr. Octave Pavy dated 13 July 1881. Greely expedition. Manuscript and Pamphlet File, National Anthropological Archives, Folder 248. Washington, D.C.: Smithsonian Institution.

Todd, A.L. 1961. Abandoned: The story of the Greely Arctic expedition 1881-1884. New York: McGraw-Hill Book Company, Inc.

Walker, D. 1872. Pavy's expedition to the North Pole. The Overland Monthly 8(6):549-555.

Weber, J.H. 1883. Prisoner at the Pole. St. Louis Globe-Democrat, September 15. 